T.T. Kozlowski (ed.). Shedding of plant parts. Academic Press, New York.

Edgerton, L.J. 1973b. Control of abscission of apples with emphasis on thinning and pre-harvest drop. Acta Hort. 34:333-343.

Greene, D.W., W.R. Autio, J.A. Erf, and Z.Y. Mao. 1992. Mode of action of benzyladenine when used as a chemical thinner on apples. J. Amer. Soc. Hort. Sci. 117:775-779.

Hartman, F.O. and F.S. Howlett. 1962. Effects of naphthaleneacetic acid on fruit setting and development in the apple. Ohio Agr. Expt. Sta. Res. Bul. 920.

Knight, J.N. 1983. Translocation properties of carbaryl in relation to its use as an apple fruitlet thinner. J. Hort. Sci. 53:371-379.

Luckwill, L.C. 1953. Studies of fruit development in relation to plant hormones. II. The effect of naphthalene acetic acid on fruit set and fruit development in apples. J. Hort. Sci. 28:25-40.

Luckwill, L.C. and C.P. Lloyd-Jones. 1962. The absorption, translocation and metabolism of 1-naphthaleneacetic acid applied to apple leaves. J. Hort. Sci. 37:190-206.

Marsh, H.V. Jr., F.W. Southwick, and W.D. Weeks. 1960. The influence of chemical thinners on fruit set and size, seed development, and pre-harvest drop of apples. Proc. Amer. Soc. Hort. Sci. 75:5-21

Murneek, A.E . 1954. The embryo and endosperm in relation to fruit development, with special reference to the apple, Malus Sylvestris. Proc. Amer. Soc. Hort Sci. 64:573-582.

Murneek, A.E. and F.G. Teubner. 1953. The dual action of naphthaleneacetic acid in thinning of apples. Proc. Amer. Soc. Hort. Sci. 61:149-154.

Rahemi, M. 1981. Role of ethylene and the effect of supplemental hand pollination in apple (Malus domestica Borkh.) fruit set. PhD Diss., Michigan State Univ., E. Lansing.

Schneider, G.W. 1973. Translocation of ${ }^{14} \mathrm{C}$-indoleacetic acid and sucrose in excised apple pedicels. J. Amer. Soc. Hort. Sci. 98:278-281.

Schneider, G.W. 1974. Ethylene evolution and apple fruit thinning. J. Amer. Soc. Hort Sci. 100:356-359.

Schneider, G.W. 1975. ${ }^{14} \mathrm{C}$-Sucrose translocation in apple J. Amer. Soc. Hort. Sci. 100:22-24.

Schneider, G.W. 1977. Studies on the mechanism of fruit abscission in apple and peach. J. Amer. Soc. Hort. Sci. 102:179-181.

Schneider, G.W. and A.M. Lasheen. 1973. NAA and Sevin on composition, development and abscission of apple fruit. HortScience 8:103-104.

Schumacher, R., R. Neuweiler, and W. Stadler. 1993. Einfluss der Fruchtausdunnung auf Fruchtansatz, Frucht-und Treibwachstum. Schweiz. Zeitschrift fur Obst- und Weinbau 129:421-426.

Southwick, R.W., W.D. Weeks, E. Sawada, and J.F. Anderson. 1962. The influence of chemical thinners and seeds on the growth rate of apples. Proc. Amer. Soc. Hort. Sci. 80:33-42.

Stopar, M., B.L. Black, and M.J. Bukovac. 1997. The effect of NAA and BA on carbon dioxide assimilation by shoot leaves of spur-type 'Delicious' and 'Empire' apple trees. J. Amer. Soc. Hort. Sci. 122:837-840.

Struckmeyer, B.E and R.H. Roberts. 1950. A possible explanation of how naphthalene acetic acid thins apples. Proc. Amer. Soc. Hort. Sci. 56:76-78.

Teubner, F.G. and A.E. Murneek. 1955. Embryo abortion as mechanism of "hormone" thinning of fruit. Missouri Agr. Expt. Sta. Bul. 590.

Tromp, J. and S.J. Wertheim. 1980. Synthetic growth regulators: Mode of action and application in fruit production, p. 137-150. In: Physiological aspects of crop productivity. Proc 15th Colloq. Intl. Potash Inst., Bern.

Walsh, C.S., H.J. Swartz, and L.J. Edgerton. 1979. Ethylene evolution in apple following post-bloom thinning sprays. HortScience 14:704-706.

Wertheim, S.J. 2000. Developments in the chemical thinning of apple and pear. Plant Growth Regulat. 31:85-100.

Williams, M.W. 1979. Chemical thinning of apples. Hort. Rev. 1:270-300.

Williams, M.W. 1981. Response of apple trees to aminoethoxyvinylglycine (AVG) with emphasis on apical dominance, fruit set, and mechanism of action of fruit thinning chemicals. Acta Hort. 120:137-141.

Williams, M.W. and L.P. Batjer. 1964. Site and mode of action of 1-naphthyl $\mathrm{N}$-methylcarbamate (Sevin) in thinning apples. Proc. Amer. Soc. Hort. Sci. 85:1-10.

Yuan, R. and D.W. Greene. 2000. Benzyladenine as a chemical fruit thinner for 'McIntosh' apples. I. Fruit thinning effects and associated relationships with photosynthesis, assimilate translocation, and nonstructural carbohydrates. J. Amer. Soc. Hort. Sci. 125:169-176.

\title{
Blossom Thinning of Pome and Stone Fruit
}

\author{
Esmaeil Fallahi ${ }^{1}$ \\ Department of Plant, Soil, and Entomological Sciences, Parma Research and Extension Center, \\ University of Idaho, 29603 U of I Lane, Parma ID 83660 \\ Kathleen M. Willemsen ${ }^{2}$ \\ Department of Horticulture and Landscape Architecture, P.O. Box 646414, \\ Washington State University, Pullman, WA 99164-6414
}

\begin{abstract}
Blossom thinners are caustic and reduce fruit set by damaging different flower parts, including anthers, stigma, style, and pollen tubes, and thus prevent fertilization. Hilderbrand (1944) studied the mode of action of the blossom thinner sodium dinitro-ortho-cresol (Elgetol, 19\% a.i.) and reported that Elgethol is a pollenicide. Early thinning of apples (Malus $\times$ domestica Borkh.) is important because of its impact on fruit size and next season flower bud initiation. In the past, apple cultivars were often sprayed with Elgethol during full bloom, followed by a post-bloom application of a fruit thinner such as 1-naphthyl N-methylcarbamate (carbaryl) with or without naphthalene acetic acid (NAA) (Williams and Edgerton, 1981). Carbaryl and NAA are effective post-bloom fruit thinners for a period of 4 to 5 weeks after full bloom (Byers et al., 1990; Byers and Carbaugh, 1991; Williams and Edgerton, 1981). Gibberellin $\mathrm{A}_{4+7}$ and 6-benzylamino purine (6-BAP) are also effective post-bloom fruit thinners for 'Delicious' apples (Byers and Carbaugh, 1991; Ferree, 1996; Greene, 1984; Greene and Lord, 1985). Elgetol was removed from the market in 1989 because of the high cost of re-registration. Elgetol's loss renewed research efforts to find blossom thinners with similar modes of action. Full-bloom
\end{abstract}

$\overline{\text { Received for publication } 13 \text { July 2000. Accepted for publication } 29 \text { Sept. } 2001 .}$ ${ }^{1}$ Professor, Tree Fruit Physiologist.

${ }^{2}$ Associate Professor, Tree Fruit Physiologist and Extension Horticulturist,Tree Fruit and Grape Production. sprays of sulfcarbamide (Wilthin, 79\% a.i.), pelargonic acid (Thinex), and endothallic acid (endothall), or petal fall applications of carbaryl (Sevin XLR Plus, 0.48 kg a.i./L; Aventis, Research Triangle Park, N.C.) were developed as replacements for Elgetol. These compounds were reported to result in satisfactory thinning and fruit set in 'Delicious' (Williams, 1993, 1994) and 'Rome' apples (Fallahi, 1997,1998; Fallahi et al., 1997).

Blossom thinning in stone fruits, particularly peaches [Prunus persica (L.) Batsch] and plums [(Prunus domestica (L.) and Prunus salicina (Lindl.)] is extremely important because of the high cost of hand thinning and lack of any post-bloom thinner. Since stages of blossom development are not as distinct as in pome fruit, it is difficult to chemically thin stone fruit blossoms. However, some blossom thinners were used to successfully thin peaches (Fallahi, 1998; Fallahi et al, 1997, 1998; Southwick et al., 1998).

\section{NEW BLOSSOM THINNERS}

Hydrogen cyanamide. Hydrogen cyanamide (Dormex, 50\% a.i.) and other chemicals were initially used to reduce chilling requirements of peaches grown in southwest Arizona (Fallahi et al., 1990). Hydrogen cyanamide applied at "pink bloom" reduced the number of open blossoms. Based on this observation, hydrogen cyanamide was sprayed at different concentrations at pre-bloom and full-bloom on 
'Florda Prince' peach in southwest Arizona (Fallahi et al., 1990). Results indicated that Dormex applied at full-bloom significantly reduced fruit set. In later studies, Dormex was also found to be an effective blossom thinner for plums (Fallahi et al., 1992), apples (Fallahi, 1997; Fallahi et al., 1997), and peaches (Fallahi, 1997) in Idaho. Fallahi (1997) reported that Wilthin, endothall, and Thinex were also, to some extent, effective for blossom thinning of apple, peach or both, but Dormex showed the most consistent results from year to year.

In commercial-scale trials, full-bloom applications Dormex at $0.25 \%$ to $0.3125 \%$ (v/v) significantly reduced fruit set in both 'Early Spur Rome' apple and 'Flavorcrest' peach. In 'Early Spur Rome', a full-bloom spray of Dormex followed by a post-bloom application of carbaryl (Sevin XLR Plus) increased fruit thinning with a significant increase in fruit size when compared to application of Dormex alone (Fallahi et al., 1998). In 'Law Rome', trees receiving a full-bloom application of Dormex followed by a post-bloom carbaryl (Sevin 4F) + NAA had significantly lower fruit set and larger fruit compared to the single carbaryl + NAA treatment. Dormex did not cause fruit marks (blemish) in apples or peaches in these trials. Dormex effectively thinned blossoms in 'Gala' and 'Delicious' apples (Fallahi et al., 1998). However, the required rate for thinning 'Delicious' is considerably lower than the effective rates for thinning 'Rome Beauty' and 'Gala' apples. In a recent experiment, Dormex at $0.0937 \%$ to $0.156 \%$ (v/v) effectively thinned 'Redspur Delicious' and 'Classic Delicious' apples (Fallahi, unpublished data). In that study, addition of $\mathrm{N}$-(phenylmethyl)-1-H-purine-6 amine (BA) plus gibberellins $\mathrm{A}_{4} \mathrm{~A}_{7}\left(\mathrm{GA}_{4+7}\right)$, a mixture commercially known as Promalin [BA, 1.8\% a.i.(w/w) and $\mathrm{GA}_{4+7}, 1.8 \%$ a.i. (w/w)] with Dormex did not show any adverse effects.

Endothallic acid. Endothall [(7, oxybicylo(2,2,2) heptane-2-3 dicarboxcylic acid, $0.5 \%$ a.i.] is an aquatic herbicide. The formulated product is a potassium salt of endothallic acid that has $0.5 \%$ a.i. In field trials in Washington, California, and Idaho, endothall is an effective blossom thinner for both apples and stone fruit. Endothall was an effective blossom thinner for 'Delicious' at $0.125 \%$ and $0.25 \%$ formulation (v/v) and for 'Fuji' at $0.25 \%$ in Washington (Williams, 1994). A full-bloom application of endothall at $0.125 \%$ and $0.187 \%$, using a hand-gun sprayer, also reduced fruit set in 'Early Spur Rome' apple in two different experiments (Fallahi, 1997 and Table 1). Endothall was an effective blossom thinner for 'Fuji' apple (Table 2) and this result is in agreement with earlier reports (Williams, 1994; Williams, 1998). Endothall effectively reduced fruit set in 'Empire', 'Delicious', and 'Gala' apples but was ineffective on 'Golden Delicious' (Byers, 1997).

Fallahi (1997) reported that endothall effectively thinned 'Redhaven' peach blossoms at $0.187 \%$, formulation (v/v) when $85 \%$ to $90 \%$ of blooms were open. However, endothall was ineffective when applied at full-bloom, when most flowers were already fertilized.
Endothall appeared to be effective in blossom thinning in 'Friar' and 'Empress' plums (Fallahi, unpublished data).

Sulfcarbamide. Monocarbamide dihydrogen sulfate or sulfcarbamide (Wilthin, 79\%, a.i.) is a mixture of urea and sulfuric acid. The chemical breaks down to sulfate and urea soon after application. Wilthin (79\% a.i.) at $0.375 \%(\mathrm{v} / \mathrm{v})$ significantly reduced fruit set in 'Delicious' (Williams, 1994) and 'Law Rome' apples (Fallahi et al., 1997); effectiveness of Wilthin in both cases were similar to that of Elgetol. Wilthin at $0.375 \%$, however, may cause fruit marking (Fallahi et al., 1997; Williams, 1994), particularly if the chemical is sprayed too late, at a time when large droplets of chemical dry on the fruit receptacles (Curry and Williams, 1992). Wilthin at $0.375 \%$ was more effective for thinning than Elgetol on 'Fuji' and 'Gala' apples (Williams, 1993). Regulaid with $90.6 \%$ a.i. as Polyoxyethylenepolypropoxypropanol at $0.125 \%$ increased the efficacy of Wilthin (Fallahi et al., 1997; Williams, 1994). Application of Wilthin at $0.25 \%$ plus Regulaid at full-bloom significantly reduced fruit set without fruit marking in 'Law Rome' apple (Fallahi et al., 1997).

Wilthin has shown mixed results in Washington and California (Johnson, 1998; Sanderson, 1998; Taylor, 1998). In some orchards, Wilthin has shown good results without any fruit marking year after year, but in other orchards, Wilthin has caused fruit marking (Sanderson, 1998 and personal communication). Wilthin has been used for blossom thinning in stone fruit, including peaches (Fallahi, 1998; Greene et al., 2001; Sanderson, 1998) and plums (Fallahi, 1998). On 'Friar' plum, full-bloom application of Wilthin at $1 \%,(\mathrm{v} / \mathrm{v})$ plus Regulaid at $0.125 \%$ (v/v), using a hand-gun sprayer, increased fruit size (Table 3 ).

Pelargonic acid. Application of the formulated product (Thinex, $60 \%$ a.i.) at $0.25 \%$ formulation $(\mathrm{v} / \mathrm{v})$ reduced fruit set in 'Delicious' apple (Williams, 1994). A single full-bloom application of Thinex at $0.25 \%$ or $0.3125 \%(\mathrm{v} / \mathrm{v})$, using a hand-gun sprayer, was ineffective in blossom thinning in 'Early Spur Rome' apple, but caused severe fruit marking in one out of two seasons of testing (Fallahi, 1997). In that experiment, however, a double application of Thinex at $40 \%$ and at $90 \%$ bloom significantly reduced fruit set. In a different experiment, a double application at $40 \%$ bloom and at full-bloom, each at a rate of $0.3125 \%(\mathrm{v} / \mathrm{v})$ mixed with Regulaid, as a surfactant, at $0.375 \%(\mathrm{v} / \mathrm{v})$, reduced fruit set in 'Early Spur Rome' apple, and the double application was significantly more effective in reduction of fruit set than a single application at full-bloom (Table 1). A full-bloom application of Thinex at $0.25 \%$ or $0.375 \%(\mathrm{v} / \mathrm{v})$ significantly reduced fruit set in 'Redhaven' peach (Fallahi, 1997).

Ammoniumthiosulfate (ATS). This fertilizer is being tested for blossom thinner activity in Canada and the United States. It has shown satisfactory to excellent thinning results on both pome and stone fruits. However, foliage and bud burning can result from application of ATS at rates above $2.5 \%$ (Fallahi, unpublished data). Byers (1997) reported that ATS was not effective in blossom thinning of 'Empire' and

Table 1. Fruit set and fruit quality in 'Early Spur Rome' treated with various blossom thinners applied with hand-gun sprayer, Sunnyslope, Idaho, $1997^{z}$

\begin{tabular}{|c|c|c|c|c|}
\hline Treatment & $\begin{array}{c}\text { Fruit set } \\
\text { (no. fruit/100 clusters) }\end{array}$ & $\begin{array}{l}\text { Mean fruit } \\
\text { wt }(\mathrm{g})\end{array}$ & $\begin{array}{l}\text { Color } \\
(1-5)^{y}\end{array}$ & $\begin{array}{c}\text { Yield } \\
(\mathrm{kg} / \text { tree })\end{array}$ \\
\hline Control (no thinning) & $140 \mathrm{a}$ & $168 \mathrm{~b}$ & $4.34 \mathrm{~b}$ & $28 \mathrm{bc}$ \\
\hline Hand thinning & $52 \mathrm{f}$ & --- & --- & --- \\
\hline Post bloom thinnerw only & $99 \mathrm{bc}$ & $230 \mathrm{a}$ & $4.58 \mathrm{a}$ & $38 \mathrm{abc}$ \\
\hline Endothal $0.125 \%$ \& Post bloom thinner & $73 \mathrm{de}$ & $215 \mathrm{a}$ & $4.43 \mathrm{ab}$ & $32 \mathrm{abc}$ \\
\hline Endothal $0.1875 \%$ \& Post bloom thinner & $31 \mathrm{~g}$ & $229 \mathrm{a}$ & $4.50 \mathrm{ab}$ & $18 \mathrm{c}$ \\
\hline $\begin{array}{l}\text { Thinex } 0.3125 \%+0.375 \% \text { Regulaid }^{w} \text { at } 40 \% \text { bloom } \\
\text { and at full bloom \& Post bloom thinner }\end{array}$ & $91 \mathrm{~cd}$ & $220 \mathrm{a}$ & $4.54 \mathrm{a}$ & $46 \mathrm{ab}$ \\
\hline Post bloom thinner & $116 \mathrm{~b}$ & $211 \mathrm{a}$ & $4.33 \mathrm{~b}$ & $43 \mathrm{ab}$ \\
\hline $\begin{array}{l}\text { Dormex at } 0.25 \% .+0.125 \% \text { Latron }^{\mathrm{w}} \text { at full bloom } \\
\quad \& \text { Post bloom thinner } \\
\text { Dormex at } 0.3125 \%+0.125 \% \text { Latron at full bloom }\end{array}$ & 75 de & 218 a & $4.54 \mathrm{a}$ & $28 \mathrm{abc}$ \\
\hline \& Post bloom thinner & 70 ef & 228 a & $4.50 \mathrm{ab}$ & $51 \mathrm{a}$ \\
\hline
\end{tabular}

${ }^{2}$ Mean separation with column by LSD at 0.05 . All\% values of chemicals in the table are based on volume per volume. ${ }^{\mathrm{y}}$ Color: $1=$ Green progressively to $5=$ dark red.

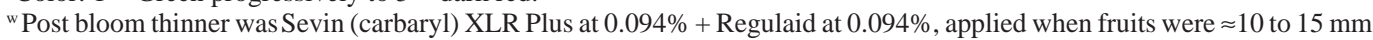
in diameter. Regulaid is a surfactant with $90.6 \%$ a.i. as polyoxyethylenepolypropoxypropanol; Latron = Latron B-1956 is a surfactant with $77 \%$ a.i. as modified phthalic glycerol alkyd resin. 
Table 2. Effects of airblast sprayer applications of ATS and endothall on fruit set and fruit weight in 'Delicious' and 'Fuji' apples, Columbia Basin area, Washington, 1997.

\begin{tabular}{lccc}
\hline \hline Treatment & $\begin{array}{c}\text { Fruit set } \\
\text { (\% control) }\end{array}$ & $\begin{array}{c}\text { Fruit set } \\
\left.\text { (fruit no./cm } \mathrm{cm}^{2} \mathrm{limb}\right)\end{array}$ & $\begin{array}{c}\text { Mean fruit } \\
\mathrm{wt}(\mathrm{g})\end{array}$ \\
\hline \multicolumn{4}{c}{ Delicious } \\
Control (no thinning) & 100 & $2.9 \mathrm{a}$ & $174.1 \mathrm{ab}$ \\
Endothall 0.125\% & 81 & $3.0 \mathrm{a}$ & $172.3 \mathrm{ab}$ \\
Endothall, 0.125\%, twice & 77 & $2.7 \mathrm{a}$ & $170.5 \mathrm{~b}$ \\
ATS 1\% & 70 & $1.6 \mathrm{a}$ & $193.3 \mathrm{a}$ \\
& & & \\
Control (no thinning) & 100 & $3.6 \mathrm{a}$ & $202.1 \mathrm{a}$ \\
Endothall, 0.125\% & 37 & $1.6 \mathrm{bc}$ & $189.8 \mathrm{a}$ \\
Endothall, 0.125\%, twice & 17 & $0.6 \mathrm{c}$ & $228.4 \mathrm{a}$ \\
Endothall 0.1875\% & 45 & $1.9 \mathrm{bc}$ & $208.4 \mathrm{a}$ \\
ATS 0.1875\% & 81 & $2.8 \mathrm{ab}$ & $216.8 \mathrm{a}$ \\
ATS 0.1875\%, twice & 58 & $1.8 \mathrm{bc}$ & $210.8 \mathrm{a}$ \\
\hline
\end{tabular}

$\overline{{ }^{2} \text { Mean separation within column of each cultivar by LSD at } 0.05 \text {. All\% values of }}$ chemicals in the table are based on volume per volume.

'Stakrimson Delicious' apples. Sanderson (1998 and personal communication) and Williams (1998) successfully reduced fruit set in different apple cultivars with rates ranging from $1.0 \%$ to $2.0 \%(\mathrm{v} / \mathrm{v})$. K.M. Williemsen (unpublished data) found that multiple applications of ATS were necessary for adequate thinning of 'Fuji' apples. Fallahi (unpublished data) applied ATS at $1.6 \%$ or $2.4 \%$ formulation ( $\mathrm{v} / \mathrm{v})$ combined with Promalin on 'Redspur Delicious' and observed satisfactory bloom thinning, without any incompatibility. The $2.4 \%$ rate resulted in slight over-thinning. Comparing several blossom thinners in 'Delicious' apple, Taylor (1998) observed the best results with ATS. Ammoniumthiosulfate at a rate of $2.4 \%$ formulation seems to be effective in blossom thinning of 'Law Rome Beauty' and 'Fuji' apples in Idaho (Fallahi, unpublished data).

Sanderson (1998) compared ATS, Wilthin, and endothall on stone fruits and reported that ATS was the best blossom thinner under Washington conditions. However, ATS applications resulted in production of some small fruit that remain on the tree and do not abscise. We believe that more tests are needed before this material can be registered for commercial use.

Other potential blossom thinners. Looney (1998) reported that fullbloom application MCPB-ethyl (a synthetic auxin) significantly reduced fruit set in 'Fuji' apple in Canada. MCPB-ethyl also reduced 'Fuji' apple fruit set in Japan (Looney, personal communication). This chemical is in the early stage of testing and only limited information on the efficacy of that is available.

Full-bloom application of the surfactant N, N-bis2-(omegahydroxypolyoxyethylenepoly-oxypropylene) ethyl alkylamine (Armothin; AKZO-Nobel, Chicago) at 3\% and 5\% (v/v) reduced fruit set in 'Loadel' peach in California (Southwick et al., 1998). Byers (1997) reported that Armothin significantly reduced fruit set but increased fruit marks in 'Golden Delicious' apple. This chemical, however, did not show a satisfactory blossom thinning in 'Red Delicious' in Washington (Taylor, 1998).

\section{EFFECTIVENESS OF BLOSSOM THINNERS}

Time and temperature are very important factors influencing the effectiveness of blossom thinning in both apple and peach. It is essential that blossom thinners be applied when some, but not all fertilization has taken place. Also the severity of frost damage must be considered before determining rates of any blossom thinner. In apples, it seems that when the king bloom is open and fertilized, and only one side bloom is open but not fertilized, is the best time to spray for blossom thinning. At this stage, the other side blooms are at "popcorn" stage or slightly (but not completely) open, and hopefully not fertilized. However, temperature and bee activity should be closely observed and taken into account for timing of blossom thinning spray. Temperature affects bee activity and thus, subsequently the number of fertilized flowers. Temperature also affects the chemical characteristics and the effectiveness of blossom thinners. Specifically, Thinex, is ineffective at temperatures
Table 3. Effects of Wilthin on 'Friar' plum yield and fruit size and color, Fruitland, Idaho, $1994^{z}$.

\begin{tabular}{lccc}
\hline \hline Treatment & $\begin{array}{c}\text { Yield } \\
(\mathrm{kg} / \text { tree })\end{array}$ & $\begin{array}{c}\text { Color }^{\mathrm{y}} \\
(1-5)\end{array}$ & $\begin{array}{c}\text { Mean fruit } \\
\mathrm{wt}(\mathrm{g})\end{array}$ \\
\hline Control & $47.5 \mathrm{ab}$ & $4.7 \mathrm{a}$ & $89.1 \mathrm{c}$ \\
Wilthin 0.5\% + 0.125\% Regulaid & $72.7 \mathrm{a}$ & $4.4 \mathrm{a}$ & $91.6 \mathrm{bc}$ \\
Wilthin $-0.75 \%$; No Regulaid & $33.9 \mathrm{~b}$ & $4.6 \mathrm{a}$ & $94.9 \mathrm{abc}$ \\
Wilthin - 0.75\% + 0.125\% Regulaid & $44.2 \mathrm{ab}$ & $4.4 \mathrm{a}$ & $96.1 \mathrm{ab}$ \\
Wilthin - 1\% + 0.125\% Regulaid & $56.6 \mathrm{ab}$ & $4.7 \mathrm{a}$ & $98.0 \mathrm{a}$ \\
\hline
\end{tabular}

${ }^{2}$ Mean separation with LSD at 0.05 . All\% values of chemicals in the table are based on volume per volume.

${ }^{\mathrm{y}}$ Color rating: $1=$ green progressively to $5=$ dark purple

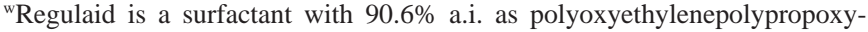
propanol.

below $10{ }^{\circ} \mathrm{C}$. Therefore, the effect of these blossom thinners should be tested for each region and for each cultivar.

Spray volume of blossom thinners could also affect fruit set (Byers, 1997; Southwick, 1998). Tree vigor may also affect fruit thinning of post-bloom thinners. It is believed that trees on dwarfing rootstocks (i.e., M.9 EMLA and M.26 EMLA) and weaker trees are somewhat more difficult to thin than vigorous trees (Adams, 1998; Johnson, 1998). Williams and Edgerton (1981) reported various tree and weather conditions affecting fruit thinning with post-bloom chemical thinners. However, little is known about the conditions that directly influence efficacy of blossom thinners, although it is our opinion that many of these conditions could have similar influences on blossom thinning and post-bloom thinning.

Complete coverage of the whole fruiting surface throughout the tree canopy is necessary. However, it is unnecessary to spray any of these materials to run-off. One should be cautious about fruit marking and leaf burning with the application of any blossom thinner. Slow drying conditions, as well as late applications, increase the possibility of fruit marking and leaf burning.

\section{CONCLUSIONS}

Several potential blossom thinners are currently being tested, and Wilthin is available for commercial use. Blossom thinning is becoming a more popular method of fruit thinning if the risk of spring frost is low. Dormex (hydrogen cyanamide) has a great potential for both pome and stone fruit blossom thinning. This blossom thinner has been extensively tested in Idaho and is currently being tested in other states. Wilthin is available for use on many apple and peach cultivars; however, more extensive testing on plums is necessary. Registration of endothall for apples in the United States is anticipated in the future.

Developing stage of blossoms should closely be monitored and blossom thinners would be more effective if applied to apples when only king blooms are fertilized, but not the side blooms. In stone fruits, blossom thinners should be sprayed when some, but not all blossoms are fertilized. Further research is needed to determine a better method for determination of the proper stage based on physiological development of pollen tube and/or fertilization of the ovules.

\section{Literature Cited}

Adams, R. 1998. Consistent tonnage needed for profitability. Good Fruit Grower 49(7):9-10.

Byers, R.E. 1997. Effects of blossom-thinning chemicals on apple fruit set. J. Tree Fruit Prod. 2:13-31.

Byers, R.E., J.A. Barden, and D.H. Carbaugh. 1990. Thinning spur 'Delicious' apple by shade, terbacil, carbaryl, and ethephon. J. Amer. Soc. Hort. Sci. 115:9-13.

Byers, R.E., and D.H. Carbaugh. 1991. Effects of chemical thinning sprays on apple fruit set. HortTechnology 1:41-48.

Curry, E.A. and M.W. Williams. 1992. New blossom thinning chemicals for apples. Proc. Plant Growth Regulat. Soc. of Amer. p. 168.

Fallahi, E. 1997. Application of endothallic acid, pelargonic acid, and hydrogen cyanamide for blossom thinning in apple and peach. HortTechnology. 7:395-399.

Fallahi, E. 1998. The use of blossom thinners for regular cropping of deciduous fruit trees. Proc. Plant Growth Regul. Soc. of Amer. p. 27-33. 
Fallahi, E., M. Kilby, and J.W. Moon. 1990. Effects of various chemicals on dormancy, maturity and thinning of peaches. Deciduous Fruit and Nut. University of Arizona, College of Agr. Rpt., Ser. P-83, p. 121-128.

Fallahi, E., R.R. Lee, and G.A. Lee. 1998. Commercial-scale use of hydrogen cyanamide for blossom thinning of apple and peach. HortTechnology 8:556-560.

Fallahi, E., B.R. Simons, J.K. Fellman, W.M. Colt. 1992. Use of hydrogen cyanamide for apple and plum thinning. Plant Growth Regulat. 11:435-439.

Fallahi, E., M.W. Williams, and W.M. Colt. 1997. Blossom thinning of 'Law Rome Beauty' apple with hydrogen cyanamide and monocarbamide dihydrogensulfate. J. Tree Fruit Prod. 2:33-44.

Ferree, D.C. 1996. Performance of benzyladenine as a chemical thinner on eight apple cultivars. J. Tree Fruit Prod. 1:33-50.

Greene, D.W. 1984. Microdroplet application of $\mathrm{GA}_{4+7}+$ BA: Sites of absorption and effects on fruit set, size, and shape of 'Delicious' apples. J. Amer. Soc. Hort. Sci. 109: 28-30.

Greene, D.W., K.I. Hauschild, and J. Krupa. 2001. Effect of blossom thinners on fruit set and fruit size of peaches. HortTechnology 11:179-183.

Greene, D.W. and W.J. Lord. 1985. Effects of chemical thinners on 'Delicious' apple trees previously sprayed with $\mathrm{GA}_{4+7}+\mathrm{BA}$. HortScience 20:84-86.

Hildebrand, E.M. 1944. The mode of action of the pollenicide, Elgetol. Proc.
Amer. Soc. Hort. Sci. 45:53-58.

Johnson, S. 1998 Consistent tonnage needed for profitability. Good Fruit Grower 49(7):9-10.

Looney, N. 1998. Chemical thinning of 'Fuji' apple. Compact Fruit Tree. Proc. Annu. Conf. Intl. Dwarf Tree Assn. 30:55-57.

Sanderson, P. 1998. Consistent tonnage needed for profitability. Good Fruit Grower 49(7):9-10.

Southwick, S.M., K.G. Weis, J.T. Yeager, and M.E. Rupert. 1998. Blossom thinning of 'Loadel' cling peach with a surfactant: Effects of concentration, carrier volume, and differential applications within the canopy. HortTechnology 8:55-58.

Taylor, J. 1998. Consistent tonnage needed for profitability. Good Fruit Grower 49(7):9-10.

Williams, K.M. 1998. Blossom thin for consistent crops. Good Fruit Grower 49(7):8.

Williams, M.W. 1993. Comparison of NAA and carbaryl petal-fall sprays of apples. HortTechnology 3:428-429.

Williams, M.W. 1994. Factors influencing chemical thinning and update on new chemical thinning agents. Compact Fruit Tree 27:115-122.

Williams, M.W. and Edgerton. 1981. Fruit thinning of apples and pears with chemicals. U.S. Dept. Agr., Agr. Bul. 289.

\title{
Chemicals, Timing, and Environmental Factors Involved in Thinner Efficacy on Apple
}

\author{
Duane W. Greene \\ Department of Plant and Soil Sciences, University of Massachusetts, Amherst, MA 01003
}

\begin{abstract}
Apple (Malus $\times$ domestica Borkh.) is a biennial bearing tree. This is characterized by heavy bloom in the 'on' year which generally leads to an overset of fruit. There are several negative consequence associated with overcropping. Many small fruit are produced, that ripen late, have poor appearance and quality, and are worth little when sold as fresh fruit. Further, flower bud formation is significantly reduced, if not totally inhibited, for the following year. Reduced cropping in the "off" year may lead to significant lower cropping, and inferior quality fruit that has a reduced postharvest storage life. In high density plantings, excessive vegetative growth may occur on lightly-cropped trees, making future management of the block difficult.

Over 50 years of experience has shown that chemical regulation of cropping is the only practical way to break this biennnial bearing cycle and reestablish more regular cropping. However, the challenges posed by chemical thinning are among the greatest obstacles fruit growers face in achieving profitable production. The chemicals and concentrations a grower chooses, the timing of their application, and the environmental factors encountered before, during, and after application all influence the ultimate thinning response. This communication will discuss the chemicals most frequently used, the circumstances when they are used and the precautions associated with their use. Also discussed will be the timing of the applications and the environmental factors one must be mindful of when applying chemical thinners.
\end{abstract}

\section{THINNING CHEMICALS}

Blossom thinners. Some of the first attempts to reduce biennial bearing involved using caustic chemicals to prevent pollination, pollen germination or pollen tube growth (MacDaniels and Hildebrand, 1940). Many of these caustic chemicals caused unacceptable phytotoxicity to the leaves and caused russeting of the fruit. The product sodium dinitroortho-cresolate (DNOC), sold commercially as Elgetol (FMC Corp., Chicago), ultimately became the material that was adopted as the blossom thinner of choice for general commercial use (Batjer and Hoffman, 1951). DNOC was used extensively in the arid fruit growing areas in western North America, but its use never became a commercial practice in the east for several reasons. Erratic weather during the bloom

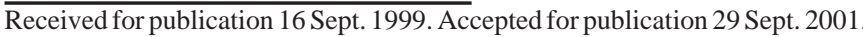

period made it difficult to determine the extent of set until after the window of opportunity for application of Elgetol passed. More phytotoxicity was encountered in the east where drying times are longer due, in large part, to the higher humidity. If rains followed application even greater phytotoxicity and excessive thinning were frequently experienced. Elgetol was removed by the manufacturer from the market in 1989 due to the high cost of reregistration. This resulted in renewed interest in identifying a safe and effective blossom thinner to replace Elgetol.

The search for replacements for Elgetol continues. Wilthin (monocarbamide dihydrogen sulfate) has proven to be an effective blossom thinner on several apple cultivars ( Byers, 1997; Fallahi et al., 1997; Williams, 1993). The herbicide endothall (7, oxabicyclo $(2,2,1)$ heptane-2-3 dicarboxylic acid) has thinning activity and commercial promise ( Byers, 1997; Williams et al., 1995). Other potential blossom thinners include pelargonic acid (MYX4801) (Byers, 1997), ammonium thiosulfate (ATS) (Byers, 1997), and Dormex (hydrogen cyanimide) (Fallahi, 1998; Fallahi et al., 1997). While all of these compounds have significant thinning activity, only after further multiple experiments conducted over several years, and under differing environmental conditions, will it be possible to determine if these blossom thinners fit into the overall thinning scheme. Most important, we must know if they can be relied on to be consistently effective.

While less frequently used, hormone sprays can thin when applied at bloom. Burkholder and McCown (1941) showed that a bloom spray of NAA and NAAm could reduce set. While this has been confirmed by later research (Jones et al., 1992), these two compounds are generally not applied commercially during bloom because of grower uncertainty about the extent of initial set and the desire to assess initial set before attempting to adjust crop load. Further, the most effective time to apply NAA as a chemical thinner is when fruit diameter is 7 to $9 \mathrm{~mm}$ (Leuty, 1973) or 11 to $13 \mathrm{~mm}$ (Tukey, 1965).

Ethephon may also thin when applied at bloom (Jones et al., 1990) or even several days earlier, at the balloon stage (Jones et al., 1983) or red stage (Wertheim, 1973). The response appears to be quite cultivar (Link, 1978) and temperature (Jones and Koen, 1985) sensitive. The use of ethephon as a blossom thinner has not be widely adopted except in locations where chemical thinning with other compounds is difficult and satisfactory results using other thinners is generally inadequate. 